\title{
Pengaruh Implementasi Teknik Team Quiz Terhadap Hasil Belajar IPA Siswa Sekolah Dasar
}

\author{
Dewi Tumatul Ainin \\ STAI Ahsanta Jambi \\ dewi.t.ainin@gmail.com \\ Yuli Amaliyah \\ STAI Ahsanta Jambi \\ yuliamaliyah405@gmail.com \\ Mardiana \\ STAI Ahsanta Jambi \\ dianamar780@gmail.com
}

\begin{abstract}
Abstrak
Penelitian ini bertujuan untuk mengetahui pengaruh implementasi teknik Team Quiz terhadap hasil belajar IPA siswa kelas V SDN 132/IV Kota Jambi Tahun Ajaran 2018/2019. Jenis penelitian ini adalah eksperimen dengan rancangan penelitian Randomized Control Group Only Design, sampel penelitian ini adalah seluruh siswa kelas V SD Negeri 132/IV Kota Jambi yang berjumlah 62 orang siswa. Hasil penelitian menunjukkan bahwa implementasi pembelajaran menggunakan teknik Team Quiz berpengaruh nyata pada taraf kepercayaan 95\% dimana hasil yang diperoleh menyatakan bahwa $t$ hitung $>\mathrm{t}$ tabel. Artinya terdapat pengaruh yang signifikan antara Implementasi pembelajaran menggunakan teknik Team Quiz terhadap tingginya hasil belajar IPA siswa kelas V SD Negeri 132/IV Kota Jambi.
\end{abstract}

Kata Kunci: hasil belajar IPA, teknik Team Quiz

\section{Pendahuluan}

Pendidikan merupakan suatu proses dimana pendidikan mengarahkan siswa untuk mampu mengembangkan potensi-potensi yang ada. Berdasarkan Undang-undang No. 20 Tahun 2003, dinyatakan bahwa tujuan Pendidikan Nasional adalah untuk mengembangkan kemampuan dan membentuk watak serta peradaban bangsa yang bermartabat dalam rangka mencerdaskan kehidupan bangsa, bertujuan untuk berkembangnya potensi peserta didik agar menjadi manusia yang beriman dan bertaqwa kepada Tuhan Yang Maha Esa, berakhlak mulia, sehat, berilmu, cakap, kreatif, mandiri dan menjadi warga Negara yang demokratis serta bertanggung jawab.

Sekolah merupakan suatu lembaga Negara yang memiliki tujuan untuk menciptakan tercapaianya tujuan pendidikan nasional dengan tanggung jawab yang besar dan diharapkan mampu menghasilkan sumber daya manusia yang berkualitas demi kemajuan bangsa di masa mendatang. Sehingga dalam rangka meningkatkan mutu pendidikan jalur sekolah, maka seorang guru diharapkan dapat mengembangkan satu atau beberapa metode atau teknik mengajar serta menggunakan media pembelajaran sesuai dengan situasi dan kondisi yang mempengaruhi kebutuhan belajar mengajar disekolah. Metode mengajar yang digunakan guru hendaknya dapat memotivasi siswa dalam memperoleh pengetahuan melalui aktivitas belajar, sehingga tujuan pembelajaran dapat tercapai 
dan pembelajaran dapat bermakna. Dalam mewujudkan pembelajaran bermakna, dalam proses pembelajaran diharapkan guru: (1)menggunakan pembelajaran terpadu, (2) mengadakan latihan kepekaan agar siswa mampu menghayati perasaan dan berpartisipasi dalam kelompok lain, dan (3) guru bertindak sebagai fasilitator dalam pembelajaran (Sagala, 2007).

Wiriasa, dkk (2017) mengemukakan bahwa sampai saat ini masih terdapat banyak keluhan dari orang tua siswa dan pakar pendidikan megenai rendahnya kemampuan siswa dalam pemahaman konsep, penerapan pembelajaran IPA pada kehidupan sehari-hari,demikian pula dengan hasil belajarnya, Hal serupa ditemukan di SDN 132/IV Kota Jambi, hasil observasi yang dilaksanakan pada tanggal 21 Oktober 2018 di kelas $\mathrm{V}$ bahwa hasil belajar siswa masih tergolong rendah. Nilai rata-rata keseluruhan hanya mencapai 58,0. Berdasarkan hasil wawancara kepada guru dan siswa, diperoleh data bahwa guru lebih banyak melakukan kegiatan mengajar dengan cara menerangkan, memberikan tugas rumah, serta membuat ringkasan. Berdasarkan hal tersebut siswa hanya menerima informasi verbal hanya dari bukubuku dan guru. Pola mengajar seperti ini yang dapat mengakibatkan cara pikir siswa menjadi tidak dapat berkembang karena dalam pembelajaran tersebut siswa hanya melakukan kegiatan mendengarkan atau menerima informasi dan kemudian menjawab pertanyaan yang diberikan oleh guru. Akibatnya siswa menjadi pasif, aktivitas pembelajaran rendah kemudian berpengaruh pada hasil belajarnya. Ini terjadi dikarenakan proses pembelajaran terkesan monoton dan tidak menarik perhatian siswa.

Mendukung pernyataan tersebut Trianto (2007) dan Setyasa (2007) menyatakan bahwa rendahnya hasil belajar siswa disebabkan oleh proses pembelajaran yang didominasi oleh pembelajaran konvensional, yaitu pembelajaran yang suasana kelas cenderung teacher centered mengakibatkan siswa menjadi pasif. Pembelajaran konvensional bersifat menghambat perkembangan perpikir siswa. Karena informasi sebagai fasilitas belajar dalam pembelajaran cenderung bersifat deduktif berupa simbolik, seperti mendengarkan penjelasan guru atau membaca. Siswa cenderung banyak menghafal saja, tidak memahami benar-benar apa yang telah dipelajari dan tidak dapat mengembangkan serta menggunakan pengetahuannya dalam kehidupan sehari-hari.

Di sisi lain, IPA merupakan pelajaran yang banyak mempelajari proses-proses yang terjadi dalam kehidupan, serta banyaknya kasus-kasus yang dihubungkan dengan kehidupan sehari-hari yang dapat dipecahkan oleh siswa secara berkolaborasi atau berkelompok. Penggunaan metode tanya jawab dan ceramah saja dirasa kurang efektif digunakan dalam penyampaian materi pelajaran IPA karena siswa hanya mengetahui hal-hal yang di tanya oleh guru dan tidak mempelajari materi secara tuntas. Pembelajaran IPA juga tidak hanya mempelajari teori-teori saja tetapi siswa diarahkan untuk melakukan kegiatan praktikum, agar daya serap terhadap materi lebih dalam lagi.

Terdapat banyak teknik atau metode pembelajaran yang dapat dilakukan untuk mengumpulkan informasi tentang kemajuan belajar siswa baik yang berhubungan dengan proses, sikap maupun hasil, teknik pembelajaran yang berhubungan dengan proses belajar adalah Team Quiz. Team Quiz merupakan suatu teknik yang bermaksud untuk meningkatkan keaktifan siswa dalam proses belajar (Wiriasa dkk, 2017). Penerapan teknik Team Quiz pada pembelajaran IPA yaitu dapat memberikan pengalaman belajar secara aktif, diskusi antar anggota kelompok sengan tujuan berbagi kemampuan, saling berpikir dan saling menghargai, menerapkan konsep IPA dan memecahkan masalah secara bersama-sama, membantu siswa memahami konsep yang sulit, menumbuhkan keterampilan social yang sangat bermanfaat bagi kehidupan 
siswa di luar sekolah. Teknik Team Quiz dapat meningkatkan sikap dan mitivasi belajar siswa karena dalam teknik Team Quiz mengintegrasikan beberapa unsur dalam pembelajaran dan memberikan penilaian dalam bentuk quiz. Berdasarkan latar belakang di atas, maka perlu dilakukan penelitian mengenai "Pengaruh Implementasi Teknik Team Quiz Terhadap Hasil Belajar Ilmu Pengetahuan Alam Siswa Kelas V SDN 132/IV Kota Jambi”.

\section{Metode}

Jenis penelitian ini adalah penelitian eksperimen. penelitian eksperimen merupakan kegiatan penelitian untuk mengontrol, memanipulasi dan mengobservasi subjek penelitian. Desain penelitian yang digunakan dalam penelitian ini adalah desain eksperimen sederhana (Posttest Only Control Group Design). Dalam desain eksperimen sederhana terdapat dua kelompok yang dipilih secara random (Sugiyono, 2010). Satu kelompok bertindak sebagai kelompok kontrol dan kelompok lain bertindak sebagai kelompok eksperimen. kelompok yang diberikan perlakuan disebut dengan kelompok eksperimen, sedangkan yang tidak diberi perlakuan disebut kelompok kontrol. kemudian pada kurun wakru yang telah ditentukan kelompok eksperimen tersebut diberi perlakuan. setelah perlakuan selesai dilakukan pengukuran terhadap kedua kelompok. perbandingan hasil antara kedua kelompok menunjukkan efek dari perlakuan yang telah diberikan.

Pada kelas eksperimen diberikan perlakukan dengan menggunakan teknik kuis tim sedangakan kelas control diberi perlakuan dengan metode sesuai silabus (metode diskusi). Pada akhir penelitian, kedua kelas diberikan tes akhir untuk mengukur hasil belajar. Populasi dalam penelitian ini adalah seluruh siswa kelas V SDN 132/IV Kota Jambi yang terdaftar pada tahun ajaran 2018/2019 yang terdiri dari dua kelas yaitu VA (32 orang) dan VB (30 orang). Sampel dalam penelitian ini adalah seluruh populasi siswa kelas V di SDN 132/IV Kota Jambi yang berjumlah 62 orang. Teknik pengambilan sampel yang digunakan adalah purposive sampling, sehingga diperoleh satu kelas sebagai kelas eksperimen dan satu kelas sebagai kelas control. Dari hasil pengambilan secara acak, maka diperoleh kelas V (lima) A sebagai kelas eksperimen dan V (lima ) B sebagai kelas control. Analisis data yang dipakai dalam penelitian ini adalah menggunakan excel dan aplikasi SPPS versi 22 .

\section{Hasil}

Berdasarkan penelitian yang dilakukan di kelas V SDN 132/IV Kota Jambi, diperoleh hasil belajar siswa pada aspek kognitif, afektif dan psikomotorik.

\section{Hasil Belajar pada Aspek Kognitif}

Hasil Belajar pada Aspek Kognitif diperoleh dari tes akhir yang dilakukan setiap akhir pokok bahasan. Adapun nilai keseluruhan pada aspek kognitif dapat dilihat pada tabel 1.1 berikut.

Tabel. 1 Hasil Belajar Aspek Kognitif

\begin{tabular}{ccc}
\hline Pokok bahasan & Kelas eksperimen & Kelas kontrol \\
\hline 1. Kalor & 84,312 & 57,2 \\
\hline 2. Siklus Air & 86,437 & 65,266 \\
\hline
\end{tabular}

Berdasarkan tabel di atas, hasil tes akhir siswa untuk pokok bahasan 1 pada kelas eksperimen yaitu 84,312 sedangkan pada kelas control 57,2. Begitu pula pada pokok bahasan 2, rata-rata tes akhir siswa kelas eksperimen yaitu 86,437 sedangkan kelas kontrol 65,266. Bila di bandingkan dengan kelas kontrol, nilai kognitif kelas eksperimen lebih tinggi. 
Tabel 2. Hasil Uji Hipotesis Aspek Kognitif

\begin{tabular}{cccc}
\hline Pokok bahasan & t hitung & t tabel & Kesimpulan \\
\hline 1. Kalor & 8,986 & 2,00 & Hipotesis Diterima \\
\hline 2. Siklus Air & 5,858 & 2,00 & HipotesisDiterima \\
\hline
\end{tabular}

Berdasarkan table di atas dapat dilihat bahwa $\mathrm{t}$ hitung $>\mathrm{t}$ tabel. Pada pokok bahasan 1 adalah 8,986 > 2,00 sedangkan pada pokok bahasan 2 adalah 5,858 > 2,00. Karena $\mathrm{t}$ hitung $>\mathrm{t}$ table maka hipotesis yang menyatakan bahwa implementasi pembelajaran dengan menggunakan teknik kuis tim berpengaruh terhadap hasil belajar pada aspek afektif siswa di kelas V SDN 132/IV Kota Jambi di terima pada taraf kepercayaan $95 \%$.

Hasil Belajar Pada Aspek Afektif

Penilaian ini dilakukan dengan menggunakan lembar pengamatan yang berisi pernyataan yang berkaitan dengan hasil penanaman nilai-nilai dari materi pelajaran.

Tabel 3. Presentase Pada Aspek Afektif

\begin{tabular}{cccccc}
\hline No & Sikap & \multicolumn{2}{c}{ Kelas eksperimen } & \multicolumn{2}{c}{ Kelas kontrol } \\
\cline { 2 - 5 } & $\begin{array}{c}\text { Pokok } \\
\text { bahasan 1 }\end{array}$ & $\begin{array}{c}\text { Pokok } \\
\text { bahasan } \\
\mathbf{2}\end{array}$ & $\begin{array}{c}\text { Pokok } \\
\text { bahasan } \\
\mathbf{1}\end{array}$ & $\begin{array}{c}\text { Pokok } \\
\text { bahasan 2 }\end{array}$ \\
\hline 1 & Kerja sama & $92 \%$ & $96 \%$ & $62,9 \%$ & $63,3 \%$ \\
\hline 2 & Tanggung Jawab & $90,8 \%$ & $92 \%$ & $75,1 \%$ & $73 \%$ \\
\hline 3 & Percaya diri & $88 \%$ & $92,3 \%$ & $59 \%$ & $60 \%$ \\
\hline 4 & Rasa ingin tahu & $89 \%$ & $93 \%$ & $37,1 \%$ & $36,7 \%$ \\
\hline
\end{tabular}

Berdasarkan tabel di atas kelas yang melaksanakan pembelajaran dengan teknik Team Quiz (kelas eksperimen) dengan jumlah sampel sebanyak 32 orang siswa pada pokok bahasan satu dan dua masing-masing sebanyak 29 dan 31 orang siswa atau sebesar 92\% dan 96\% siswa yang memiliki sikap 'Kerja Sama' yang baik. Siswa yang memiliki sikap 'Bertanggung Jawab' sebanyak 29 orang siswa atau sebesar 90,8\% dan 92\%. Siswa yang memiliki sikap 'Percaya Diri' sebanyak 28 dan 29 siswa atau sebesar $88 \%$ dan 92,3\%. Siswa yang memiliki sikap 'Rasa Ingin Tahu' sebanyak 28 dan 30 orang siswa atau sebesar $89 \%$ atau $93 \%$.

Sedangkan kelas kontrol dengan jumlah sampel sebanyak 30 orang siswa pada pokok bahasan satu dan dua masing-masing sebanyak 19 siswa yang memiliki sikap 'Kerja Sama' yang baik atau sebesar 62,9\% dan 63,3\%. Siswa yang memiliki sikap 'Bertanggung Jawab' masing-masing sebanyak 22 orang siswa atau sebesar 75,1\% dan 73\%. Siswa yang memiliki sikap 'Percaya Diri' masing-masing sebanyak 18 orang siswa atau sebesar 59\% dan 60\%. Siswa yang memiliki sikap 'Rasa Ingin Tahu' masing-masing sebanyak 11 orang siswa Atau sebesar 37,1\% atau 36,7\%. Berdasarkan data yang diperoleh tersebut, dapat diartikan implementasi teknik Team Quiz pada mata pelajaran IPA di SDN 132/IV Kota Jambi dapat meningkatkan aspek sikap (psikomotorik) siswa.

Hasil Belajar Pada Aspek Psikomotor

Penilaian hasil belajar pada aspek psikomotor dilakukan dengan menggunakan lembar tes unjuk kerja yaitu pada keterampilan proses.

Tabel 4. Presentase Nilai Siswa Pada Aspek Psikomotor

\begin{tabular}{cccccc}
\hline No & $\begin{array}{c}\text { Kategori } \\
\text { keterampilan }\end{array}$ & \multicolumn{2}{c}{ Kelas eksperimen } & \multicolumn{2}{c}{ Kelas kontrol } \\
\cline { 3 - 6 } & $\begin{array}{c}\text { Pokok } \\
\text { bahasan 1 }\end{array}$ & $\begin{array}{c}\text { Pokok } \\
\text { bahasan } \\
\mathbf{2}\end{array}$ & $\begin{array}{c}\text { Pokok } \\
\text { bahasan } \\
\mathbf{1}\end{array}$ & $\begin{array}{c}\text { Pokok } \\
\text { bahasan 2 }\end{array}$ \\
\hline 1 & Sangat baik & $68,7 \%$ & $75 \%$ & $34 \%$ & $33,3 \%$ \\
\hline
\end{tabular}




\begin{tabular}{lccccc}
\hline 2 & Baik & $28,2 \%$ & $21,9 \%$ & $16,7 \%$ & $20 \%$ \\
\hline 3 & Cukup & $25 \%$ & $9,4 \%$ & $6,7 \%$ & $6,7 \%$ \\
\hline 4 & Kurang & $3,1 \%$ & $3,1 \%$ & $6,7 \%$ & $6,7 \%$ \\
\hline
\end{tabular}

Dari tabel diatas terlihat bahwa aspek psikomotor pada kelas eksperimen pokok bahasan 1 dan 2 masing-masing yang memiliki kategori 'Sangat Baik' sebanyak 22 dan 24 orang siswa atau sebesar 68,7\% dan 75\%. Siswa memiliki Kategori 'Baik' sebanyak 9 dan 7 orang siswa atau sebesar 28,125\% dan 21,9\%. Siswa memiliki kategori 'Cukup' sebanyak 8 dan 3 orang siswa atau sebesar $25 \%$ dan $9,4 \%$. Siswa yang memiliki kategori 'Kurang' sebanyak 1 orang siswa atau sama-sama 3,1\%.

Sedangkan pada kelas kontrol pokok bahasan 1 dan 2, siswa memiliki kategori 'Sangat Baik' sebanyak 10 orang siswa atau sebesar 34\% dan 33,3\%. Siswa memiiki Kategori 'Baik' sebanyak 5 dan 6 orang siswa atau sebesar 16,7\% dan 20\%. Siswa memiliki Kategori 'cukup' sebanyak 2 orang siswa atau sebanyak 6,7\%. Siswa memiliki kategori 'kurang' sebanyak 2 orang siswa atau sebanyak $6,7 \%$.

Tabel 5. Uji Hipotesis Aspek Psikomotor

\begin{tabular}{cccc}
\hline Pokok bahasan & t hitung & t tabel & Kesimpulan \\
\hline Pokok bahasan 1 & 2,069 & 2,00 & Hipotesis diterima \\
\hline Pokok bahasan 2 & 2,089 & 2,00 & Hipotesis diterima \\
\hline
\end{tabular}

Berdasarkan tabel di atas dapat dilihat bahwa $\mathrm{t}$ hitung $>\mathrm{t}$ tabel. Pada pokok bahasan 1 adalah 2,069 > 2,00 sedangkan pada pokok bahasan 2 adalah 2,089 2,00. Karena t hitung > t table maka hipotesis yang menyatakan bahwa implementasi teknik Team Quiz berpengaruh terhadap hasil belajar aspek psikomotorik siswa di kelas V SDN 132 Kota Jambi di terima pada taraf kepercayaan 95\%.

\section{Pembahasan}

Berdasarkan hasil analisis data yang dilakukan pembelajaran dengan menggunakan teknik Kuis Tim dapat meningkatkan hasil belajar siswa. Hal ini dapat dilihat dari data yang diperoleh pada aspek kognitif bahwa rata-rata hasil belajar siswa yang diberi perlakuan dengan menggunakan metode ini tampak sangat baik yaitu 84,312 pada materi 1 dan 86,37 pada materi 2 . Sementara pada kelas control, dimana tidak diberi perlakuan dengan metode tersebut (pembelajaran dengan metode konvensional), rata-rata hasil belajar siswa 57,2 pada materi 1 dan 65,266 pada materi 2.

Pada aspek afektif, diperoleh hasil bahwa siswa yang diberi perlakuan dengan menggunakan teknik Team Quiz memiliki hasil belajar aspek afektif yang lebih tinggi dibanding siswa yang tidak diberi perlakuan, Pada kelas eksperimen pokok bahasan 1 terdapat 29 orang siswa atau sebesar $92 \%$ yang memiliki sikap "kerja sama' yang baik, pada kelas kontrol hanya terdapat 19 orang siswa atau sebesar $62,9 \%$. Sedangkan kelas eksperimen pada Pokok bahasan 2 terdapat 31 orang siswa atau sebesar $96 \%$ yang memiliki memiliki sikap 'kerja sama' yang baik, pada kelas kontrol hanya terdapat 19 orang siswa atau sebesar 63,3\%. Artinya, sikap 'kerja sama' dapat terjalin dengan baik ketika terjadi interaksi dan kekompakan dengan teman dalam kelompok untuk mengatasi atau memecahkan permasalahan bersama. Terlihat adanya interaksi yang baik diantara siswa yang memiliki pengetahuan tinggi, sedang dan rendah. Siswa yang berkemampuan tinggi tampak aktif menjadi mentor bagi siswa yang berkemampuan sedang dan rendah. Demikian juga dengan siswa yang berkemampuan rendah, tampak lebih semangat dalam mengikuti pelajaran. 
Sikap memiliki 'Tanggung Jawab' yang baik diperoleh oleh kelas eksperimen pada pokok bahasan 1 yaitu sebanyak 29 orang siswa atau sebesar 90,8\%, pada kelas kontrol hanya terdapat 22 orang siswa atau sebesar $75,1 \%$. Sedangkan pada kelas eksperimen pokok bahasan 2 terdapat sebanyak 29 orang siswa atau sebesar $92 \%$, pada kelas kontrol hanya terdapat 22 orang siswa atau sebesar $73 \%$. Hal ini berarti bahwa, kegiatan dalam implementasi teknik Team Quiz dapat meningkatkan rasa tanggung jawab siswa akan tugas yang diberikan yaitu menyelesaikan tugas dan unjuk kerja, tanggung jawab memandu kuis, tanggung jawab dalam kelompok baik sebagai maupun sebagai ketua, keberanian siswa dalam mempertahankan pendapat, Sejalan dengan penelitian Murdani (2015) dengan judul "Penggunaan Kuis Tim untuk Meningkatkan Tanggung jawab Individu dalam Kelompok Belajar Geografi Siswa Kelas X-8 SMA Negeri 1 Durenan Trenggalek" dengan hasil penelitian bahwa penggunaan pendekatan metode pembelajaran aktif tim telah dapat meningkatkan tanggungjawab individu dalam kelompok belajar. bahwa terdapat peningkatan indikator sikap tanggung jawab pada siswa dengan semakin meningkatnya kualitas penyelesaian tugas dan unjuk kerja. Sedangkan pada kelas kontrol, sikap tanggung jawab siswa berupa kemampuan siswa dalam menyelesaikan tugas yang diberikan oleh guru. Tujuan utama siswa yaitu mendapatkan nilai yang baik dengan menghafalkan materi yang diberikan oleh guru atau di buku paket sekolah. Pembelajaran seperti itu terkesan dipaksakan, siswa menerima materi dengan terpaksa karena tuntutan kurikulum bukan karena kebutuhan siswa sendiri. Siswa belajar IPA merasa kurang termotivasi dan hasil belajar IPA siswa. Akibatnya sebagian siswa merasa tidak mampu mengikuti pembelajaran kemudian beberapa orang siswa mengabaikannya.

Pada kelas eksperimen sikap 'Percaua Diri' siswa cenderung lebih tinggi dibandingkan dengan siswa pada kelas kontrol. Ini terlihat dari sebanyak 28 orang siswa atau sebesar $88 \%$ siswa yang memiliki sikap 'Percaya Diri' pada pokok bahasan 1, dan sebanyak 29 orang siswa atau sebesar 92,3\% pada pokok bahasan 2 . Sedangkan pada kelas kontrol, siswa yang memiliki sikap 'Percaya Diri' pada pokok bahasan 1 dan 2 masing-masing sebanyak 18 orang siswa atau sebesar $59 \%$ dan $60 \%$. Ini berarti kepercayaan diri siswa dapat ditumbuhkan dan ditingkatkan melalui pembelajaran dengan teknik Team Quiz. Ciri dari pembelajaran Team Quiz yang telah diterapkan dalam kelas eksperimen seperti mengajukan pertanyaan, menjawab pertanyaan. penyampaian pendapat, dan mempresentasikan/pengajaran teman sekelas dapat menumbuhkan dan meningkatkan kepercayaan diri siswa. Sedangkan itu pada kelas control presentase siswa yang memiliki rasa percaya diri adalah lebih kecil, hal ini terjadi karena kegiatan pembelajaran yang dilaksanakan secara konvensional yaitu berpusat pada guru. Siswa menjadi pasif dan kurang ada kesempatan untuk berbicara atau berkomunikasi dalam forum kelas. Siswa menjadi canggung dan tidak terbiasa untuk berbicara di depan umum.

Sikap 'Rasa Ingin Tahu' yang tinggi diperoleh di kelas eksperimen pada pokok bahasan 1 dan 2 dengan masing-masing sebanyak 28 orang siswa atau sebesar $89 \%$ dan 30 orang siswa atau sebesar 93\%. Sedangkan pada kelas kontrol pada pokok bahasan 1 dan 2 masing-masing diperoleh sebanyak 11 orang siswa atau sebesar $37,1 \%$ dan $36,7 \%$. Hal ini menunjukkan bahwa melalui implementasi teknik Team Quiz ini siswa siswa dapat memiliki rasa ingin tahu yg lebih besar karna pada tahapan Team Quiz ini mereka terlibat langsung dalam proses pembelajaran. Siswa mendapatkan dorongan untuk aktif bekerja baik secara individu maupun kelompok sehingga memumculkan rasa ingin tahu dalam menemukan suatu konsep. Arend (dalam Murdani, 2015) Penyelidikan Otentik (Authentic Investigation) merupakan salah satu ciri utama dalam pembelajaran Team Quiz, bahwa siswa melakukan penyelidikan untuk mencari solusi yang nyata dari masalah yang nyata artinya dalam hal ini diperlukan analisis masalah, hipotesis, melacak informasi dan sumber, melakukan eksperimen dan menyimpulkan merupakan wujud dari kegiatan untuk 
meningkatkan rasa ingin tahu siswa. siswa dapat secara aktif berpartisipasi dalam merancang, merencanakan, menyiapkan, melaksanakan, menilai, mengevaluasi kegiatan pembelajaran dengan suasana lebih menyenangkan (Joyfull Learning). Keterlibatan secara langsung dan menyenangkan ini merupakan pengalaman kebermaknaan hidup dalam belajar, baik makna yang dirumuskan maupun yang dihayati. Siswa menjadi lebih termotivasi untuk secara bersama-sama dalam (1) mengumpulkan informasi, yaitu dapat menumbuhkan rasa ingin tahu siswa; (2) berdiskusi, yaitu menumbuhkan sikap kerja sama yang baik dan tanggung jawab; (3) presentasi dalam kelompok belajar, yaitu menumbuhkan dan meningkatkan rasa percaya diri siswa dalam proses pembelajaran.

Pada aspek psikomotor siswa secara umum telah mencapai kategori 'Sangat Baik' yaitu sebesar $68,7 \%$ pada pokok bahasan 1 dan $75 \%$ pada pokok bahasan 2 . Dalam hal ini adalah keterampilan proses dalam pembelajaran IPA ketika siswa sedang melaksanakan praktikum untuk menemukan konsep pada materi pokok 1 dan 2 yang dilaksanakan sebelum masuk pada teknik Team Quiz. Aspek yang diukur adalah aspek mengamati, melakukan percobaan, aspek menyimpulkan dan aspek mengkomunikasikan. Siswa tampak aktif dalam mencari tahu dan berusaha mengikuti tahapan peraktikum secara sistematis. Sedangkan pada kelas kontrol jumlah presentase lebih kecil yaitu sebesar $32,7 \%$ pada pokok bahasan 1 dan sebesar $33,3 \%$. Pada kelas ini aspek keterampilan siswa kurang lebih kecil karena kegiatan pembelajaran dalam kelas kontrol ini cenderung secara konvensional, tidak dilaksanakan praktikum dan materi disampaikan langsung kepada siswa melalui ceramah dari guru atau membaca dan mencatatnya dari buku paket. Dengan demikian dapat disimpulkan bahwa pembelajaran menggunakan teknik Team Quiz berpengaruh terhadap hasil belajar IPA siswa kelas V sdn 132/IV Kota Jambi.

Penelitian ini sejalan dengan penelitian yang telah dilakukan sebelumnya oleh (1) Sitio (2018) dengan judul "Penerapan Strategi Pembelajaran Aktif Tipe Quiz Team untuk Meningktakan Hasil Belajar IPA Siswa Sekolah dasar” dalam Jurnal Review Pendidikan dan Pengajaran (JRPP) hasil penelitiannya menyatakan bahwa penerapan strategi pembelajaran tipe Team Quiz dapat meningkatkan hasil belajar sains materi siklus air dan kejadian alam; (2) Wiriasa, dkk (2017) dengan judul Pengaruh Implementasi Teknik Team Quiz Terhadap Hasil Belajar IPA Ditinjau dari Sikap Ilmiah Siswa Kelas VI SD Gugus I Kecamatan Kuta Selatan hasil penelitiannya dinyatakan terdapat perbedaan hasil belajar IPA antara siswa yang mengikuti teknik Team Quiz dengan siswa yang mengikuti teknik pembelajaran konvensional pada siswa; dan (3)Wita (2013) pada penelitiannya yang berjudul "Implementasi Metode Pembelajaran Team Quiz (Kuis Kelompok) Untuk Meningkatkan Prestasi Belajar Sejarah Siswa Kelas XI IPS 4 SMAN 1 Sewon" hasil penelitiannya menyatakan bahwa Metode pembelajaran Team Quiz yang dipadukan dengan media peta konsep dan permainan kuis cepat-tepat dapat meningkatkan prestasi belajar sejarah siswa.

\section{Simpulan}

Berdasarkan hasil analisis data dari hasil belajar siswa pada aspek kognitif, afektif dan psikomotor serta hasil pembahasan dari penelitian ini, maka dapat disimpulkan bahwa implementasi pembelajaran menggunakan teknik Team Quiz berpengaruh nyata pada taraf kepercayaan 95\% dimana hasil yang diperoleh menyatakan bahwa t hitung > t tabel, artinya implementasi teknik Team Quiz terhadap hasil belajar IPA siswa berpengaruh signifikan terhadap tingginya hasil belajar IPA SDN 132/IV Kota Jambi yaitu pada aspek kognitif, afektif dan psikomotor.

Penggunaan metode ini dapat meningkatkan hasil belajar pada aspek kognitif/pengetahuan siswa dapat dilihat dari nilai yang diperoleh semakin baik, 
dari aspek afektif/sikap, siswa pada kelas yang diberi perlakuan lebih baik daripadasiswa kelas kontrol (yang tidak diberi perlakuan). Dari aspek psikomotorik, siswa kelas kontrol yang diberi perlakuan pembelajaran dengan teknik Team Quiz hasilnya lebih terampil dari pada siswa kelas kontrol.

\section{Referensi}

Alwasilah, C. (2007). Menulis dengan Metode Kolaborasi. Bandung. Kiblat.

Murdani. (2015). Penggunaan Kuis Tim untuk Meningkatkan Tanggung jawab Individu dalam Kelompok Belajar Geografi Siswa Kelas X-8 SMA Negeri 1 Durenan Trenggalek. Jurnal PINUS, 1, 3 Oktober 2015. ISSN 2442-916.

Nasution, S. (2010). Berbagai Pendekatan Dalam Proses Belajar dan Mengajar. Bandung: Bumi Aksara.

Nisa Hayati. (2013). Pengaruh Penerapan Model Pembelajaran Kolaboratif Teknik Group Investigation Terhadap Kemampuan Berfikir Analisis Peserta Didik. Journal.upi.edu/index.php/managerial, 3, 5/Juli 2018.

Saprijono, A. (2009). Cooperative Learning Teori and Aplikasi PAIKEM. Yogyakarta. Pustaka Pelajar

Sitio, Satriana. (2018). Penerapan Strategi Pembelajaran Aktif Tipe Quiz Team untuk Meningktakan Hasil Belajar IPA Siswa Sekolah dasar. Jurnal Review Pendidikan dan Pengajaran(JRPP).

Sudjana, N. (2009). Penilaian Hasil Proses Belajar Mengajar. Bandung. Remaja Rusdakarya

Sugiyono. (2010) Metode Penelitian Kuantitatif, Kualitatif dan R\&D. Bandung:Alfabeta.

Sulistyawati, Nanik \& Darmiyati Zuchdi. (2016). Implementasi Teknik Pembelajaran

Kolaboratif dengan Variasi Media untuk Peningkatan Hasil Belajar di SMPN 2 Kali Jambe. Harmoni Sosial: Jurnal Pendidikan IPS p-ISSN: 2356-1807 eISSN:2460-7916.

Surakhmat, W. (2016). Pengantar Interaksi Belajar. Bandung. Tarsito.

Trisnawaty, Fikria \& Slameto. (2017). Peningkatan Hasil Belajar IPA Melalui Penggunaan Metode Demonstrasi Pada Siswa Kelas 4 SD. Satya Widya, 33, 1. Juni 2017: 37-44.

Wiriasa, I Gusti Putu Jul dkk. (2017). Pengaruh Implementasi Teknik Team Quiz Terhadap Hasil Belajar IPA Ditinjau dari Sikap Ilmiah Siswa Kelas VI SD Gugus I Kecamatan Kuta Selatan. E-Journal Program Pascasarjana Universitas Ganesha Program Studi Pendidikan Dasar, 7, 1 Tahun 2017.

Wita, Stevania. (2013). Implementasi Metode Pembelajaran Team Quiz (Kuis Kelompok) untuk meningkatkan Prestasi Belajar Sejarah Siswa Kelas XI IPS 4 SMAN 1 Sewon Tahun Ajaran 2012/2013. E-Jurnal UniversitasNegeri Yogyakarta, 2, 2 Agustus 2013. 